\title{
STRATEGI KETAHANAN PANGAN DALAM PROGRAM URBAN FARMING DI MASA PANDEMI COVID-19 OLEH DINAS KETAHANAN PANGAN DAN PERTANIAN KOTA SURABAYA
}

\author{
Olivia Agustin Nailatul Wardah \\ S1 Ilmu Administrasi Negara, Fakultas Ilmu Sosial dan Hukum, Universitas Negeri Surabaya \\ oliviaanwardah@gmail.com \\ Fitrotun Niswah \\ S1 Ilmu Administrasi Negara, Fakultas Ilmu Sosial dan Hukum, Universitas Negeri Surabaya \\ fitrotunniswah@unesa.ac.id
}

\begin{abstract}
Abstrak
Pemerintah lewat Dinas Ketahanan Pangan dan Pertanian Kota Surabaya telah mengupayakan berbagai program yang diharapkan mampu mengatasi permasalahan terkait pemenuhan kebutuhan pangan pasca pandemi COVID-19 yang sedang terjadi, contohnya dalam pemanfaatan program Urban Farming yang bertujuan mengatasi permasalahan kebutuhan pangan pasca pandemi. Sehingga dari permasalahan tersebut tujuan yang ingin dicapai ialah dapat mengetahui, menggambarkan serta mendeskripsikan bagaimana upaya strategi ketahanan pangan melalui program pertanian perkotaan yang digagas oleh DKPP Kota Surabaya. Urban Farming awalnya ditujukan kepada masyarakat miskin untuk bekal memulai pembudidayaan tanaman yang dimanfaatkan guna pemenuhan pangan mandiri untuk menuju kesejahteraan. Teknik pengumpulan data yang digunakan dalam metode penelitian kualitatif deskriptif ini ialah studi kepustakaan. Fokus yang diambil oleh peneliti merujuk pada 5 strategi utama menurut (Hanafie,2010). Hasil penelitian menunjukkan bahwa dalam lima indikator yang dianalisis ditemukan fakta yang meliputi, prioritas pembangunan ekonomi berbasis pertanian yang dimanfaatkan di perkotaan; pemenuhan pangan pasca pandemi COVID-19; pemberdayaan masyarakat terkait program Urban Farming; promosi dan edukasi terkait program tersebut; dan penanganan keamanan terhadap jaminan mutu pangan yang segar; bahwa peran dan langkah yang dilakukan Pemerintah Kota Surabaya dinilai sangat efektif. Hal ini ditinjau lewat meningkatnya tren positif dalam pemanfaatan program Urban Farming oleh masyarakat Kota Surabaya. Namun perlunya perbaikan proses sosialisasi serta promosi agar program dapat berjalan dengan baik tanpa hambatan dan kendala.
\end{abstract}

Kata Kunci: Strategi, Ketahanan Pangan, Urban Farming

\begin{abstract}
The government, through Food and Agriculture Service Office, has pursued various programs that are expected to be able to overcome problems to meeting food needs after the COVID-19 pandemic, for example in the Urban Farming program which aims to address the problem of post-pandemic food needs. From these problems, the goal to be achieved is to be able to find and describe how the food security strategy efforts through the urban agricultural program. Urban Farming was originally aimed at the poor to provide supplies to start cultivating plants that are used to fulfill independent food for prosperity. The data collection technique used in this research method is literature study. The focus taken by the researcher refers to the 5 main strategies according to (Hanafie, 2010). The results showed that in the five indicators analyzed, facts were found which include, agricultural-based economic development priorities that are utilized in urban areas; fulfillment of food after the COVID-19 pandemic; community empowerment related to the Urban Farming program; promotion and education related to the program; and security handling of fresh food quality assurance; that the roles and steps taken by the Surabaya City Government are considered very effective. This is observed through the increasing positive trend in the use of the Urban Farming program by the people of the City of Surabaya. However, it is necessary to improve the socialization and promotion process so that the program can run well without obstacles and obstacles.
\end{abstract}

Keywords: Strategy, Food Security, Urban Farming

\section{PENDAHULUAN}

Tahun 2020 merupakan tahun yang sangat merugikan masyarakat seluruh dunia dikarenakan adanya ekspansi Pandemi COVID-19 yang terjadi sejak akhir tahun 2019. Pernyataan tersebut juga sejalan dengan pernyataan dalam suatu jurnal bahwa, dunia telah terpukul parah oleh pandemi COVID-19 dan krisis ekonomi yang mengikutinya. Sehingga pentingnya produksi pangan berdaulat dan cadangan pangan sehingga akses ke sumber pangan tetap terjaga pada saat darurat mengizinkan negara untuk 
memberikan bantuan makanan kepada kelompok tertentu dalam kondisi khusus.

"in times of emergency the important role of the state to provide food assistance to certain groups in special conditions by increasing food production and improving access to existing

food sources."(Made and Uli 2020)

Pernyataan diatas merupakan bukti bahwa terpuruknya kondisi di seluruh dunia akibat ekspansi COVID-19 yang menyebabkan sektor paling vital yakni perekonomian dan produksi pangan di Dunia terganggu dan berada di titik mengkhawatirkan.

Arah gelombang pandemi COVID-19 di Indonesia diawali dari kofirmasi pertama di bulan Maret hingga saat ini statistik mencatat bahwa pada tanggal 4 Oktober 2020 (dilansir dari sumber: Peta Sebaran COVID-19)(Komite Penanganan COVID-19 dan Pemulihan Ekonomi Nasional 2020), yang memberikan data terkait COVID-19 sebagai berikut.

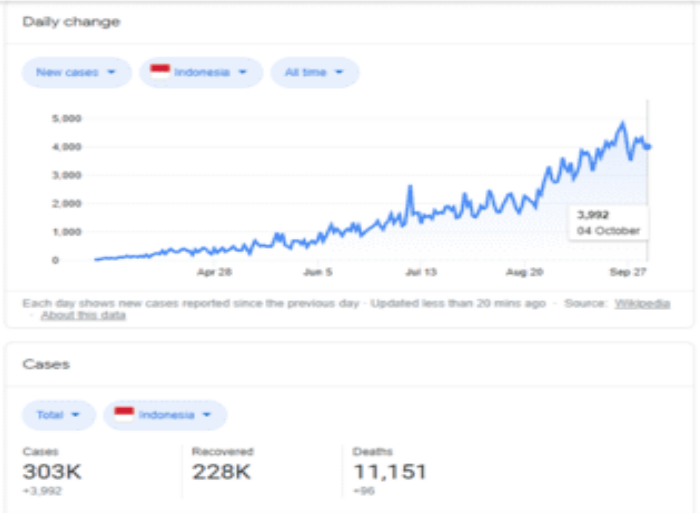

Gambar 1. Statistik Pertumbuhan COVID-19 di Indonesia pada 4 Oktober 2020

Sumber : Satgas Penanganan COVID-19 2020.

Disebutkan pada data diatas sebanyak 3,002 pasien dikonfirmasi positif COVID-19 pada tanggal 4 Oktober dengan rincian data pasien per wilayah (dilansir dari sumber: Peta Sebaran COVID19)(Komite Penanganan COVID-19 dan Pemulihan Ekonomi Nasional 2020), yang menggambarkan data konfirmasi COVID-19 di Indonesia sebagai berikut.

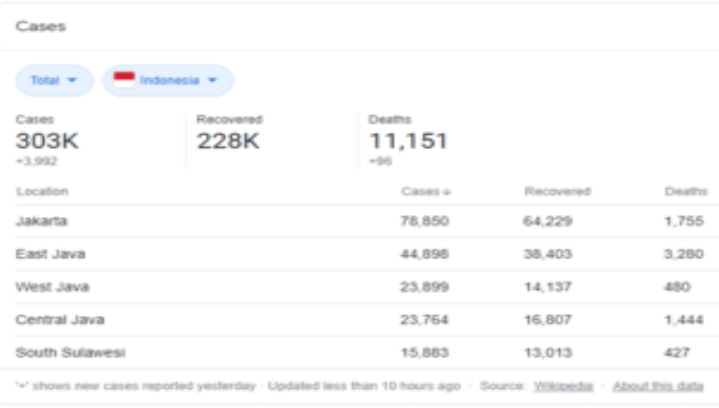

Gambar 2. Persebaran Pasien COVID-19 per Wilayah di Indonesia pada 4 Oktober 2020 Sumber : Satgas Penanganan COVID-19 2020.
Pandemi COVID-19 berdampak di semua sektor kehidupan di Indonesia, salah satunya dalam sektor pertanian. Hal ini sejalan dengan pernyataan dalam sebuah artikel yang bersumber dari situs BKP Kementrian Pertanian (BKP 2020) terkait penyiapan strategi bagaimana cara menangani permasalahan COVID-19 tentang kebutuhan pangan. Peran strategis sektor pertanian dalam membantu pembangunan perekonomian nasional berupa berbagai bidang seperti perkebunan, perhutanan, perikanan,dll. Sebanyak $31.9 \%$ lapangan pekerjaan dari total angkatan kerja di Indonesia (2016) diakibatkan oleh sektor pertanian secara strategis sehingga dapat memperoleh prosentase sebesar 13,38\% dalam GNP Indonesia (2014) (Khoirunnas 2019). Namun saat ini masih rendahnya pola perilaku masyarakat perkotaan yang memanfaatkan budaya pertanian seperti di pedesaan menjadikan hal tersebut suatu permasalahan baru yang ditemukan di perkotaan dikarenakan banyak perilaku masyarakat yang konsumerisme dari pada menjadi produsen akan pemenuhan kebutuhan barang pokok. Adanya paradigma bahwa yang bisa melakukan dan menjalankan produksi yaitu masyarakat desa, padahal banyak hal yang tentunya dapat dilakukan juga di kota-kota besar dengan mayoritas mata pencaharian nya bukan bertani ataupun berkebun. Seperti pernyataan dalam jurnal tentang pentingnya keterlibatan produksi mandiri di tiap rantai keluarga.

"30 to 40 percent of the community's needs can

be obtained from the fulfillment of food needs

through the family environment participating by

planting and gardening” (Hagey, Rice, and

Flournoy 2012)

Keluarga yang berpartisipasi dalam komunitas berkebun mampu mengimbangi biasanya 30 hingga 40 persen kebutuhan produksi mereka dengan makan makanan ditanam di kebun mereka sendiri. Dalam hal ini untuk memperbaiki dampak akibat COVID-19 bisa dilakukan dengan menerapkan berbagai cara seperti mencoba untuk memproduksi secara mandiri kebutuhan pangan karena hal itu dapat memenuhi kebutuhan masyarakat tiap individu.

Pada awalnya tren ketahanan pangan yang ada di Indonesia dipengaruhi oleh peran BULOG sebagai penyedia dan mengatur kebutuhan bahan pangan masyarakat. Dalam pernyataan berikut, peran BULOG diperluas untuk mengontrol beberapa komoditas lain seperti gula, tepung, daging, jagung, kedelai, kacang tanah, kacang hijau, serta telur dan ayam khususnya pada saat Idul Mubarak dan Natal. Namun sejak krisis Indonesia tahun 1998, peran tersebut telah berubah total akibat tekanan 
internasional untuk meliberalisasi perekonomian Indonesia. Sejak itu, BULOG kembali mengontrol beras saja (Panuju, Mizuno, and Trisasongko 2013). Dalam keterangan tersebut kesimpulan yang dapat diambil bahwa tugas Bulog pernah menangani pengadaan bahan pokok selain beras namun sejak adanya krisis, Bulog kembali seperti semula dengan tugas hanya mengontrol pengadaan beras baik yang dipasok dari petani-petani maupun impor dari negara lain.

Diperlukannya upaya guna memperbaiki pola perilaku masyarakat Indonesia agar berpindah menjadi negara yang dapat memproduksi kebutuhan terutama di sektor pangan. Upaya yang dilakukan pemerintah harus bertujuan untuk menekan angka penurunan tingkat ketahanan pangan yang diakibatkan oleh serangan wabah COVID-19. Dalam pernyataan suatu jurnal menyebutkan bahwa,

"the main determinants of behavioural

intention is social norms and pressure that

appear inside of society"(Carzedda and

Nassivera 2021).

Disebutkan jika pada kenyataannya, baik dalam lingkaran keluarga, teman maupun umum merupakan pendorong untuk merubah perilaku untuk memproduksi kebutuhan. Sehingga dalam hal ini fokus pemerintah adalah dengan mengajak masyarakat untuk perlahan lahan merubah kebiasaan ke arah produksi bahan makanan secara mandiri.

Apabila terpenuhinya suatu kebutuhan akan pangan bagi negara sampai dengan perseorangan, terlihat dari tersedianya kebutuhan pangan baik dalam jumlah maupun mutunya yang bersifat aman, beragam, bergizi, merata, dan terjangkau ataupun tidak bertentangan dengan budaya, keyakinan masyarakat untuk menuju kehidupan yang layak, sehat, serta produktif secara berkelanjutan dinakan ketahanan pangan dalam Peraturan Pemerintah tentang Ketahanan Pangan (Undang-undang 2015). Hal ini didukung dengan pernyataan dalam suatu jurnal bahwa, syarat memperoleh ketahanan pangan ditinjau dari fleksibilitas dan kempuan adaptasi serta kapasitas dalam menyerap guncangan pasar dan lingkungan guna memanfaatkan dan mempertahankan suatu rantai makanan agar berfungsi penuh dan stabil.

"requirement of the resilience is how people can

have flexibility and adaptability as

well"'(Bakalis and Valdramidis 2020).

Dalam pernyataan diatas hal-hal yang menjadi fokus pada aspek ketahanan adalah bagaimana kemampuan beradaptasi terhadap permasalahan yang timbul. Untuk saat ini permasalahan terbesar yang bersinggungan langsung dengan siklus pemenuhan kebutuhan pangan yang ada yaitu dengan munculnya COVID-19. Upaya yang dilakukan nantinya diharapkan dapat memperbaiki segala permasalahan yang timbul di Indonesia terkait pengadaan pangan maupun mengenai ekspor impor yang dilakukan dan dijalankan oleh pemerintahan. Dalam kenyataannya menurut pernyatan seperti berikut,

"higher price is the way for rice farmers made

by policy makers think that this is choice for

stimulate production and improve food security

in indonesia"'(Timmer 2019).

Namun pembuat kebijakan tampaknya berpikir bahwa petani beras membutuhkan harga yang lebih tinggi untuk merangsang produksi, dan karenanya untuk meningkatkan ketahanan pangan Indonesia. Hal tersebut membuat Pemerintah harus memiliki opsiopsi lain untuk mengatasi permasalahan akan kebutuhan pangan di Indonesia. Dilain sisi Pemerintah telah membuat berbagai program yang nantinya dapat meningkatkan indeks perekonomian maupun dalam lingkup ketahanan pangan masyarakat. Hal ini banyak dilakukan di berbagai tempat seperti di pedesaan untu meningkatkan swasembada pangan, selain itu program perbaikan ini juga dilakukan di perkotaan seperti halnya di Kota Surabaya.

Surabaya merupakan salah satu metropolitan di Indonesia. Pemerintah yang ada Kota Surabaya juga memiliki upaya-upaya demi merubah pola perilaku masyarakat perkotaan dalam hal berdudidaya, bertani, dan berkebun untuk memproduksi segala kebutuhan di sektor pangan. Program-program yang digagas bervariasi mulai dari adanya inovasi perbaikan fasilitas-fasilitas taman kota, penyediaan fasilitas sosialisasi di bidang pertanian, dan program-program lain yang nantinya bertujuan untuk merubah sikap konsumerisme masyarakat kota Surabaya menjadi berproduksi untuk memenuhi kebutuhan masingmasing maupun khalayak umum. Hal ini pula didasari oleh konsep strategi dalam ketahanan pangan yang dilakukan oleh Pemerintah.

Peran sektor pertanian yang ada di kota ini relatif kecil dan cenderung menurun setiap tahunnya dalam struktur ekonomi yang ada. Penurunan yang ada disebabkan oleh identitas kota Surabaya yang lebih kearah aktivitas perdagangan dan jasa (Wiyanti 2013). Dalam penerapan program Urban Farming yang ada pada Dinas Ketahanan Pangan dan Pertanian menerapkan dan memberi contoh langsung bagaimana implementasi terkait pemanfaatan Urban Farming yang dapat dilakukan oleh masyarakat khususnya Kota Surabaya. Berikut dokumentasi 
terkait tanaman yang ada pada Dinas Ketahanan Pangan dan Pertanian.

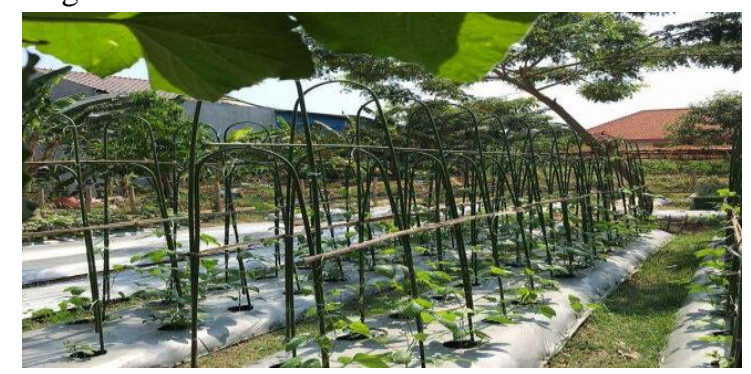

Gambar 3. Potret sayuran yang dikembangkan di Fasilitas Dinas Ketahanan Pangan dan Pertanian. Sumber : Dokumentasi penelitian Implementasi Program Urban Farming Dinas Ketahanan Pangan Dan Pertanian Kota Surabaya.

Salah satu program terkait kontrol dan pemanfaatan yang dikaitkan dengan membangun kembali strategi dalam pemenuhan kebutuhan pangan yang ada di Kota seperti Surabaya dibawahi oleh DKPP yang menangani masalah ketahanan pangan dan kebutuhan akan pertanian Kota Surabaya dinamakan pertanian perkotaan atau Urban Farming. Program ini digagas pada awal 2009 di Dinas Ketahanan Pangan dan Pertanian sebagai penanggungjawab program. Program ini awalnya ditujukan kepada masyarakat miskin sebagai bekal untuk memulai pembudidayaan tanaman yang nantinya dimanfaatkan guna pemenuhan kebutuhan pangan oleh masyarakat dan menjadikannya batu loncatan untuk menuju kesejahteraan.

Permasalahan tentang pemenuhan kebutuhan pangan untuk mencapai ketahanan pangan lewat aspek produksi yang dirasa cukup memprihatinkan saat pandemi COVID-19 sejalan dengan pernyataan bahwa,

"in the production aspect the problem of food security begins with a massive increase in food production"(Andoko and Doretha 2019).

Dalam pemenuhan kebutuhannya, cara yang dilakukan untuk mengatasi adalah meningkatan aspek produksi secara masif namun dalam kenyataannya di Indonesia masih banyak masyarakat yang mengalami kekurangan pangan.

Upaya yang direalisasikan lewat program pertanian perkotaan yang bertujuan untuk tetap menjaga kualitas hidup, dengan perbaikan konsumsi berkualitas dalam setiap lapisan masyarakat. Desain yang digunakan juga menyesuaikan situasi dan kondisi perkotaan Kota Surabaya yang tidak banyak memiliki lahan kosong. Selain itu, kontribusi yang ada dalam manfaat digalakkannya program pertanian perkotaan ini adalah ruang terbuka hijau kota yang semakin luas dan ketahanan pangan yang akan teratasi dengan baik tanpa timbul masalah baru (Santoso et al.
2014). Sehingga dapat disimpulkan bahwa program Urban Farming adalah suatu program yang direalisasikan berupa kegiatan pemanfaatkan lahan sempit dan tidak terpakai di lingkup perkotaan milik pemerintah maupun perseorangan. Diharapkan adanya program ini dapat meningkatkan penghijauan yang ada di Surabaya.

Program Urban Farming secara umum dikatakan memiliki perbedaan yang tidak cukup signifikan, perbedaan utamanya adalah lahan yang digunakan. Akibat landscape perkotaan yang cenderung padat pemukiman sehingga memang tidak dimaksudkan sebagai pusat produksi bahan pangan. Namun, untuk mengatasi berbagai permasalahan yang dihadapi lewat realisasi program ini dengan ditingkatkannya pemanfaatan ruang minimalis di perkotaan melalui pembudidayaan tanaman sesuai arahan urban farming (Nugraheni, 2013) (Qowiyyum, Nailatul Wardah, and Dkk 2020).

Dalam penelitian terdahulu terkait evaluasi program Urban Farming menghasilkan laporan bahwa manfaat yang telah dirasakan lewat program ini yaitu meningkatnya kadar oksigen di Kota Surabaya menjadi 0,2\% (Qowiyyum et al. 2020), dan juga diharapkan dalam penelitian terkait strategi ketahanan pangan lewat program yang dijalankan terus menerus dapat melatih serta merubah perilaku berbudidaya yang ada di masyarakat Surabaya apalagi melihat situasi saat ini yang masih dihantui oleh pandemi COVID-19.

Program ini sendiri juga digunakan untuk mengatasi pemenuhan kebutuhan dalam pangan yang akhir-akhir ini mengalami masalah, seperti pada masalah impor bawang putih yang merupakan salah satu komoditi terpenting dalam pemenuhan kebutuhan masyarakat Indonesia yang di impor dari China mengalami masalah dikarenakan munculnya COVID-19 (corona virus disease).

"for agricultural exports originating from

affected regions historically and however that

strict border controls have often been

observed." (Chen and Mao 2020).

Secara historis, bagaimanapun juga kontrol perbatasan yang ketat sering diamati untuk ekspor pertanian yang berasal dari daerah yang terkena dampak. Tahun lalu jumlah impor komoditi bawang putih mencapai 600 Ton yang tertulis dalam sebuah artikel yang berisi pernyataan Dirjen Hortikultura Kementerian Pertanian Prihasto Setyanto terkait aktivitas impor untuk komoditas sayur dan buah, bawang putih yang ternyata menjadi komoditi terbesar yang diimpor pada Agustus 2019 (Siregar 2019). Namun akibat adanya COVID-19 di tahun 
2020 mengakibatkan terhentinya pasokan bawang putih di Indonesia dikarenakan petani bawang putih masih kurang untuk memenuhi kebutuhan seluruh masyarakat apalagi dengan dihentikannya sementara impor bawang putih dari negera China. Ungkapan tersebut dituangkan oleh Menteri Perdagangan Agus Suparmanto bahwa akan dilakukannya penghentian sementara akan produk produk impor yang dikirim dari China selama masih adanya wabah virus corona (Mahardika and Jatmiko 2020). Dalam penghentian tersebut cadangan bawang putih yang masih ada sudah dipersiapkan penyediannya dan dirasa akan mencukupi serta memenuhi kebutuhan masyarakat Indonesia.

COVID-19 dalam hal ini berperan sangat besar dalam perubahan pola perilaku serta bagaimana Pemerintah bertindak dalam melakukan manage disetiap sektor maupun program yang ada seperti dalam pelaksanaan program ini. Kegiatan masyarakat yang terganggu di setiap sektor kehidupan perlahanlahan dapat membantu adanya realisasi terkait strategi pemenuhan kebutuhan bahan pokok lewat produksi mandiri seperti dalam tujuan dibuatnya program Urban Farming.

Dalam karya Pengantar Ekonomi Pertanian (Hanafie 2010) adanya ketahanan pangan diharapkan nantinya respon masyarakat mampu untuk mewujudkan kemandirian pangan lewat strategistrategi yang akan diterapkan guna mencapai keberhasilan dalam membangun ketahanan pangan, harapan yang akan dicapai nantinya disimpulkan sebagai berikut (Rep and Pembangunan 2006) :

1. Dapat meningkatnya produksi secara keseluruhan baik dalam supply maupun daya beli masyarakat terutama masyarakat miskin.

2. Meningkatkan daya beli masyarakat khusunya bagi masyarakat miskin yang kekurangan pangan dengan dilakukannya lewat pendistribusian supply pangan ke daerah daerah yang mengalami defisit pangan.

Pemerintah Kota Surabaya membuat suatu strategi dalam perbaikan di sektor pengadaan pangan melalui program Urban Farming ini. Strategi ini meliputi bagaimana upaya dan sinergi antara DKPP Kota Surabaya dan masyarakat khususnya Kota Surabaya dalam pemenuhan kebutuhan pangan sehingga tercapai ketahanan pangan pada masa gelombang pandemi COVID-19. Kegiatan pertanian perkotaaan merupakan salah satu upaya Pemerintah Kota Surabaya dalam memberdayakan masyarakat khusunya dalam sektor pertanian. Nantinya diharapkan lewat program ini pula terjadi peningkatan dalam pemberdayaan ekonomi masyarakat berpenghasilan rendah maupun pengurangan akan masalah kemiskinan di Kota Surabaya lewat Urban Farming (Humas Bangga Surabaya 2020). Penerapan yang nantinya dilakukan secara intens melalui program Urban Farming yang didasarkan pada 5 strategi yang nantinya menjadi fokus dalam penelitian ini, meliputi, prioritas pembangunan ekonomi berbasis pertanian yang dimanfaatkan di perkotaan, pemenuhan pangan pasca pandemi COVID-19, pemberdayaan masyarakat terkait program Urban Farming, promosi dan edukasi terkait program tersebut, dan penanganan keamanan terhadap jaminan mutu pangan yang segar. Strategi tersebut dapat menjadi landasan yang nantinya digunakan untuk memberikan pengertian akan pentingnya pemanfaatan program Urban Farming di masa Pandemi COVID-19. Sehingga dari berbagai masalah yang ada membuat peneliti tertarik untuk melakukan penelitian mengenai aspek, "STRATEGI KETAHANAN PANGAN DALAM PROGRAM URBAN FARMING DI MASA PANDEMI COVID-19 OLEH DINAS KETAHANAN PANGAN DAN PERTANIAN KOTA SURABAYA" yang nantinya penelitian ini menggali setiap informasi yang dinilai relevan menurut teori yang digunakan tentang bagaimana strategi ketahanan pangan dimasa pandemi COVID-19 melalui pemanfaatan program pertanian perkotaan yang dibuat oleh Dinas Ketahanan Pangan dan Pertanian di Kota Surabaya.

\section{METODE}

Penelitian ini menggunakan pendekatan deskriptif kualitatif yang nantinya lebih menekankan kedalam aspek gambaran bagaimana keadaan dalam mencapai strategi ketahanan pangan lewat program Urban Farming dikarenakan jenis penelitian yang diambil yakni melalui library research atau studi kepustakaan. Teknik pengumpulan data maupun informasi dengan menelaah berbagai sumber seperti buku-buku, literatur-literatur, catatan-catatan dan laporan-laporan yang ada hubungannya dengan masalah yang dipecahkan menurut M. Nazir ialah studi kepustakaan (Nazir 2019). Lokasi yang diambil dalam penelitian ini adalah di Dinas Ketahanan Pangan Dan Pertanian Kota Surabaya terkait fokus program Urban Farming. Fokus penelitian ini dimaksudkan untuk membatasi penelitian guna memilih mana data yang relevan dan yang tidak relevan, agar tidak dimasukkan ke dalam sejumlah data yang sedang dikumpulkan walaupun data itu menarik. Fokus penelitian yang diambil dari arah kebijakan menurut (Hanafie, 2010) tentang 
pemantapan ketahanan pangan yang dilakukan dengan 5 (lima) strategi utama (Hanafie 2010), meliputi:

1. Memprioritaskan pembangunan ekonomi berbasis pertanian dan perdesaan untuk:

(a) meningkatkan kapasitas produksi pangan domestik

(b) menyediakan lapangan kerja

(c) meningkatkan pendapatan masyarakat

2. Pemenuhan pangan bagi kelompok masyarakat terutama masyarakat miskin kronis dan transien (akibat bencana alam, sosial dan ekonomi) melalui pendistribusian bantuan pangan.

3. Pemberdayaan masyarakat supaya mampu memanfaatkan pangan beragam, bergizi seimbang dan aman (B2SA) berbasis sumber daya lokal.

4. Promosi dan edukasi kepada masyarakat untuk memanfaatkan pangan B2SA berbasis sumber daya lokal.

5. Penanganan keamanan dan mutu pangan segar. Pengumpulan data yang dilakukan dalam penelitian studi kepustakaan ini berisi kegiatan untuk menghimpun informasi yang relevan dengan topik atau masalah yang menjadi obyek penelitian. Informasi tersebut diperoleh dari berbagai sumber baik buku, karya ilmiah, internet, dan sumber-sumber lain yang nantinya dijadikan sebagai acuan dalam penelitian (Transiskom.com 2016). Dalam penelitian ini terbagi dalam sumber primer dan sekunder. Sumber primer dalam penelitian studi kepustakaan berisi tentang sumber data langsung yang didapatkan lewat pernyataan ahli-ahli di bidang penanganan ketahanan pangan.

"sources that have been inside primary include statistical data, manuscripts, speeches, interviews, works or art and literature, research reports, government documents" (Elmer E. Rasmuson Library 2020).

Pernyataan tersebut sejalan dengan penelitian ini karena didasarkan pada perolehan data dari sumber statistik, literatur resmi, dan dokumen dari pemerintah yang tersedia.

"They way for describe some problems, then analyze, and/or evaluate information found in primary sources are studies by other researchers is secondary sources"

Bahwa sumber sekunder adalah studi oleh peneliti lain. Mereka mendeskripsikan, menganalisis, dan / atau mengevaluasi informasi yang ditemukan dalam sumber primer. Dengan mengemas ulang informasi, sumber sekunder membuat informasi lebih dapat ditemukan. Beberapa contoh sumber sekunder adalah buku, artikel jurnal dan majalah, kamus, indeks berkala, dan ulasan, dll). Jadi, sumber sekunder penelitian ini menekankan pada analisis yang dilakukan dalam studi peneliti lain yang dikemas ulang dalam bentuk artikel baru.

Hal ini dapat dijadikan sebagai teknis pengumpulan data yang lebih ditekankan dalam pencarian informasi lewat sumber literer yang nantinya diolah dengan menyesuaikan ke dalam fokus penelitian yang digunakan sebagai dasar. Teknik analisis data yang digunakan dalam penelitian ini ialah lebih menekankan pada analisi isi dari informasi yang ditemukan dalam penemuan sumber sumber sekunder yang ditekankan oleh peneliti (Nazir 2019). Analisis isi disini merupakan langkah yang bersifat pembahasan mendalam terhadap isi suatu informasi tertulis atau tercetak. Analisis tersebut memiliki beberapa langkah mulai dari menentukan permasalahan, menyusun kerangka pemikiran, menyusun perangkat metodologi dengan menentukan metode analisis mana yang nantinya akan digunakan peneliti, analisis data, dan intepretasi data, yang nantinya akan menemukan titik terang bahwa tujuan penelitian studi kepustakaan ini adalah mengkaji teori strategi utama dalam pemantapan ketahanan pangan menurut Hanafie, 2010 dengan masalah yang ada saat ini melalui pemanfaatan program Urban Farming oleh Dinas yang secara khusus menangani permasalahan akan pangan dengan digunakannya opsi dalam program pertanian perkotaan di Kota Surabaya. Pada akhirnya penggunaan penelitian-penelitian terdahulu yang relevan juga diperlukan untuk dilakukan pengkajian informasi terhadap aspek-aspek yang sesuai dengan topik penelitian yang diangkat.

\section{HASIL DAN PEMBAHASAN}

Berdasarkan hasil penelitian yang telah dilakukan dengan berbagai teknik pengambilan data diantaranya dengan cara observasi lapangan terkait fokus penelitian strategi ketahanan pangan dan menggali berbagai informasi lewat studi kepustakaan yang dilakukan. Sesuai dengan indikator dalam teori yang digunakan mencakup fokus tentang 5 strategi utama yang menjadi pokok bahasan dalam penelitian meliputi, prioritas pembangunan ekonomi berbasis pertanian yang dimanfaatkan di perkotaan; pemenuhan pangan pasca pandemi COVID-19; pemberdayaan masyarakat terkait program Urban Farming; promosi dan edukasi terkait program tersebut; dan penanganan keamanan terhadap jaminan mutu pangan yang segar; yang dijabarkan lebih detail sebagai berikut.

1. Memprioritaskan pembangunan ekonomi berbasis pertanian dan perdesaan 
Pada awalnya dalam proses pemenuhan kebutuhan pangan sebelum adanya COVID-19 menunjukkan bahwa statistik Nilai Tukar Petani Jawa Timur pada bulan Desember 2019 naik sebesar 0,48 persen dari 108,97 menjadi 109,49 disebabkan oleh kenaikan indeks harga komoditi pangan yang dipaparkan sebagai berikut (Badan Pusat Statistik 2020),

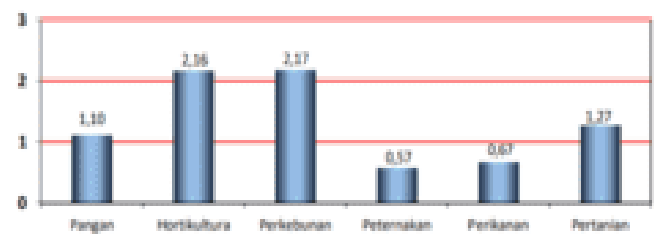

Gambar 4. Grafik Perubahan Indeks Harga Diterima Petani (It) Jawa Timur Bulan NovemberDesember Tahun 2019 (2012=100)

Sumber : BPS Kota Surabaya 2019

Apabila dilihat dari grafik diatas, komoditi tanaman hortikultura berada diurutan kedua dalam grafik perubahan indeks harga yang diterima petani pada tahun 2019. Sedangkan pada tahun 2020 grafik yang ada mengalami perubahan yang sangat signifikan sebagai berikut,

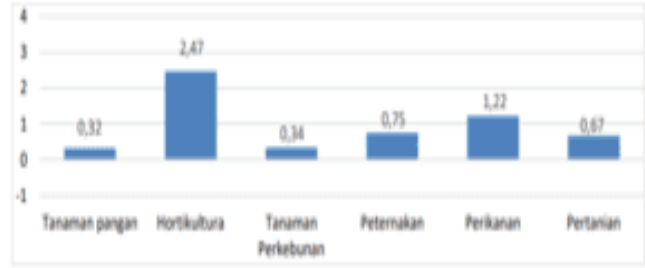

Gambar 4. Grafik Perubahan Indeks Harga Diterima Petani (It) Jawa Timur Bulan NovemberDesember Tahun 2020 (2018=100)

Sumber : BPS Kota Surabaya 2020

Grafik diatas menunjukkan bahwa dalam subyek komoditi hortikultura menjadi komoditi yang meningkat pada bulan Desember 2020, hal ini tidak lepas dari peran adanya COVID-19 selama setahun sehingga dari grafik tersebut pula menunjukkan bahwa penghasilan petani hortikultura meningkat pasca pandemi.

Dalam hal prioritas pembangunan ekonomi pasca pandemi COVID-19 Pemerintah Kota Surabaya telah melakukan berbagai cara untuk memperbaiki dan membangun kembali perekonomian berbasis pemanfaatan bahan pangan yang terdapat pada opsi dalam program Urban Farming. Hal ini dilakukan karena masyarakat miskin yang ada di Kota Surabaya pada tahun 2020 mengalami peningkatan dibandingkan dengan tahun 2018 dan 2019 (BPS 2020). Adapula grafik yang disajikan sebagai berikut,

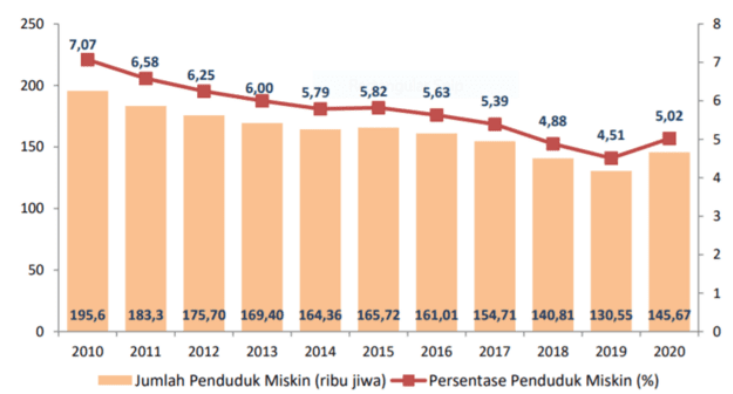

Gambar 5. Jumlah dan Persentase Penduduk Miskin Kota Surabaya, 2010-2020

Sumber : BPS Kota Surabaya 2020

Dalam indikator ini pula telah diuraikan lebih lanjut beberapa langkah yang ada dalam kegiatan prioritas guna menunjang pembangunan ekonomi dengan melihat realisasi yang dijalankan lewat program Urban Farming, diantaranya meliputi:

a) Meningkatkan kapasitas produksi pangan domestik. Pada awalnya fokus program Urban Farming sejak tahun 2009 diberikan kepada masyarakat kalangan menengah kebawah dengan hasil seperti dalam Langkah yang dilakukan dalam upaya meningkatkan kapasitas produksi pangan di Kota Surabaya disampaikan lewat pernyataan Kepala Badan Perencanaan Pembangunan Kota Surabaya yang menyatakan bahwa program Urban Farming ini nantinya tidak hanya berfokus pada pemenuhan pangan seperti beras, tetapi juga dalam pemenuhan komoditi pangan seperti jagung, singkong, maupun sumber karbohidrat lainnya dapat menjadi opsi lain untuk pemenuhan kebutuhan (Liputan6.com 2020).

Persebaran yang ada dalam implementasi Urban Farming di Kota Surabaya dipaparkan sebagai berikut,

Tabel 1. Lokasi Kegiatan Pengembangan Pertanian Perkotaan (Urban Farming)

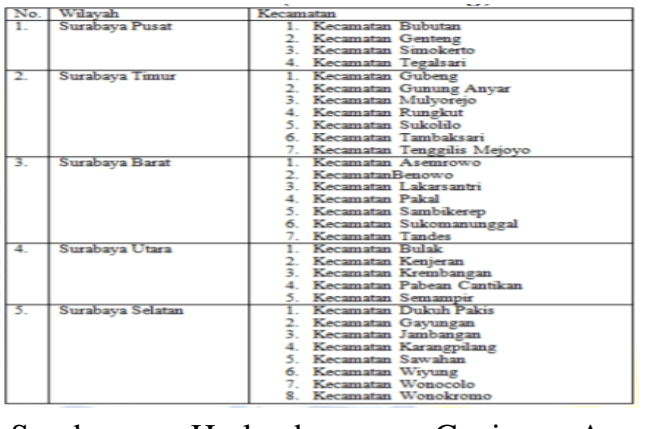

Sumber: Herlambang, Ganis Ayu, Implementasi Program Urban Farming di Kelurahan Made Surabaya: 2011 (Sihgiyanti; 2016) 
Kapasitas produksi pangan di Kota Surabaya menunjukkan tren positif dengan peningkatan permintaan akan bibit yang disediakan oleh Dinas Ketahanan Pangan dan Pertanian. Hal ini dikuatkan dengan pernyataan bahwa,

"Pada awal tahun 2020 hingga bulan

Juli permintaan bibit sudah melebihi

80.000, berbanding terbalik dengan

permintaan bibit pada tahun 2017 dan

2018 yang hanya mencapai angka 5.000

hingga 10.000 yang disampaikan oleh

Kepala Dinas Yuniarto Herlambang"

(Hakim and AS 2020)

Sehingga dari paparan diatas menunjukkan bahwa upaya dalam meningkatkan kapasitas produksi domestik Kota Surabaya dilaksanakan dengan pemanfaatan program Urban Farming yang digagas oleh Dinas Ketahanan Pangan dan Pertanian.

b) Menyediakan lapangan kerja. Dari data yang ada menunjukkan bahwa pada bula Maret tahun 2020 jumlah penduduk miskin mencapai 145.670 orang meningkat 15.120 dari tahun 2019. Dalam hal ini, upaya Dinas Ketahanan Pangan dan Pertanian memberikan sosialisasi dan pelatihan terkait pendirian usaha baru pasca pandemi dikarenakan hal ini juga berhubungan dengan adanya peningkatan data PHK dan pegawai yang harus dirumahkan akibat COVID-19 (Kurniawan 2020). Sehingga pembekalan masyarakat lewat pelatihan-pelatihan usaha baru terutama dalam bidang pemanfaatan Urban Farming untuk meningkatkan ketahanan pangan di wiliayah Kota Surabaya dilaksanakan oleh Pemerintah. Pembekalan ini meliputi pelatihan dalam memanfaatkan dan memasarkan inovasi lewat program Urban Farming seperti membuka usaha baru dalam lingkup makanan sehat khusus untuk diet (Komarudin 2020), ataupun inovasi lain yang di dokumentasikan dalam laman Youtube seperti dalam UKM binaan DKPP yang tersebar di beberapa wilayah seperti di Kecamatan Wonocolo, Tambak Sari, dan Sukomanunggal yang tergabung dalam wadah Kawasan Rumah Pangan Lestari. Pelatihan serta pembinaan yang dilakukan tidak terlepas dari fungsi serta manfaat program Urban Farming dalam memberikan lapangan pekerjaan khususnya bagi Ibu Rumah Tangga. Berikut salah satu dokumentasi KRPL Serpis Kecamatan Wonocolo, Kota Surabaya (Dinas
Ketahanan Pangan dan Pertanian Kota Surabaya 2020).

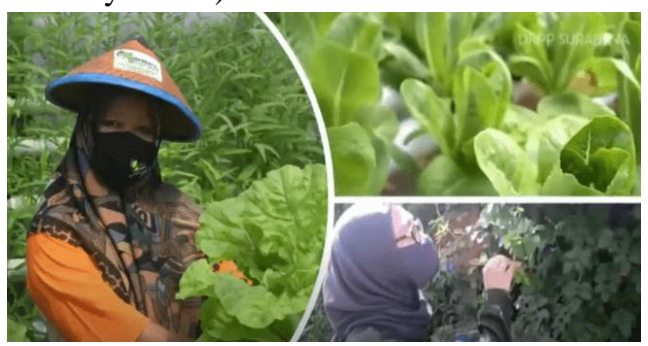

Gambar 6. Dokumentasi KRPL Serpis Wonocolo, Surabaya

Sumber : Youtube DKPP Kota Surabaya

c) Meningkatkan pendapatan masyarakat. Apabila dikaitkan dengan 2 poin diatas maka bukan tidak mungkin bahwa Urban Farming dapat meningkatkan pendapatan masyarakat Kota Surabaya perlahan-lahan membaik pasca Pandemi COVID-19. Dinas Ketahanan Pangan dan Pertanian memperkenalkan wadah untuk menjual maupun membeli produk-produk yang dihasilkan lewat program Urban Farming. Pernyataan tersebut juga sejalan dari sumber yang mengemukakan pendapat oleh Kepala Badan Perencanaan Pembangunan (Bappeko) sebagai berikut, jika dalam upaya untuk meningkatkan pelaksanaan program Urban Farming, Pemerintah memberikan fasilitas berupa wadah yang di realisasikan ke dalam Citraland Fresh Market yang nantinya berguna dalam menunjang aktivitas pemasaran produk masyarakat" (Kurnia and Murdaningsih 2020). Fresh Market sendiri merupakan sebuah pasar semi tradisional yang didirikan di wilayah masyarakat kalangan menengah keatas dan borjuis. Terkait harga yang ditawarkan memang agak sedikit lebih mahal daripada pasar tradsional namun bias dikatakan lebih murah dibandingkan pasar modern atau supermarket. Selain itu di sini pula tempat memasarkan berbagai produk pemanfaatan Urban Farming yang didapat dari beberapa wilayah di Surabaya seperti produk dari kampung hidroponik Medokan Ayu (Zahro and Sholichfudin 2020). Di Citraland Fresh Market memberikan inovasi baru yang dibuat melihat situasi dan kondisi akibat adanya pandemi COVID-19 yaitu lewat pembayaran non-tunai. Penggunaan pembayaran cashless ini juga disebutkan pada artikel yang membahas tentang bagaimana jalannya proses jual beli yang dilakukan 
dengan bantuan aplikasi Miber (Wijayanto 2020). Namun yang lebih diprioritaskan selain pemanfaatan program tersebut di wilayah rumah tangga namun juga memperbaiki pola perilaku masyarakat agar lebih berpikir pada orientasi pemenuhan kebutuhan pangan demi meningkatnya ketahanan pangan yang ada. Sehingga apabila masyarakat perlahan-lahan memperbaiki sikap tersebut dalam pemenuhan kebutuhan pangan akan sejalan dengan hasil yang didapat meningkatnya pendapatan. Begitu pula disaat COVID-19 aktivitas yang ada di Pasar ini menerapkan protokol kesehatan yang ketat (Yuana and Anshori 2020).

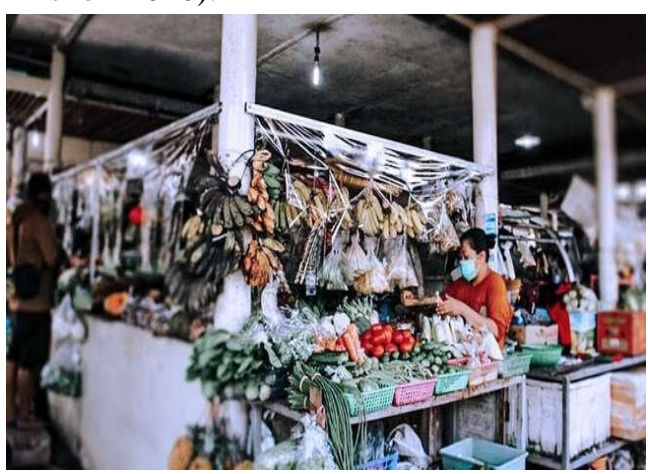

Gambar 7. Kondisi Citraland Fresh Market yang menggunakan protokol kesehatan ketat saat COVID.

Sumber : Dokumentasi Timesindonesia, Surabaya

2. Pemenuhan pangan bagi kelompok masyarakat terutama masyarakat miskin kronis dan transien (akibat bencana alam, sosial dan ekonomi) melalui pendistribusian bantuan pangan.

Pemenuhan pangan menjadi hal yang harus diatasi dimasa pandemi saat ini, sesuai dengan pernyataan dalam sebuah jurnal bahwa terdapat permasalahan terkait distribusi pangan yang berakibat dalam pemenuhan pangan itu sendiri sehingga tentunya bahwa masyarakat menjadi subyek terdampak akibat COVID-19. Gangguan logistik yang diakibatkan oleh larangan sosial seperti PSBB mempengaruhi distribusi makanan ke banyak daerah di Indonesia seperti pernyataan suatu jurnal,

"COVID-19 contain has affected the food

distribution to many region in social

restrictions"(Rahman 2020).

Fenomena tersebut terjadi diakibatkan oleh semakin meluasnya dampak COVID-19 sehingga upaya pencegahan maupun penanggulangan yang dilakukan pemerintah lewat implementasi dan pengembangan kembali program Urban Farming.
Pada awalnya Urban Farming merupakan suatu program yang dikhususkan untuk masyarakat miskin di Kota Surabaya yang dibekali pelatihan agar dapat mengatasi permasalahan terkait pemenuhan kebutuhan pangan individu. Namun dengan adanya pandemi COVID-19 pemenuhan pangan masyarakat dibuat skenario baru dengan pendistribusian Bantuan Sosial Beras sebanyak 15kg tiap KK dalam satu bulan. Bantuan ini dikhususkan kepada masyarakat yang terdata kurang mampu agar tetap terpenuhi kebutuhan pangannya. Setiap KPM (Keluarga Penerima Manfaat) yang dijadwalkan sebanyak tiga kali untuk menerima $15 \mathrm{~kg}$ beras medium dari Perum Bulog (ANP 2020). Bantuan yang diberikan oleh pemerintah tidak hanya tersebar di Kota Surabaya saja namun juga tersebar di daerah lain seperti, Jawa Tengah, Jawa Barat, Jakarta, dan daerah lain dikarenakan menurut sumber artikel menyatakan bahwa,

"Perum Bulog menyalurkan 450 ribu ton beras kepada 10 juta KPM-PKH" (CNN Indonesia 2020)

Sehingga nantinya sebanyak 10 juta warga yang terdafttar akan mendapatkan batuan selama tiga bulan dari Pemerintah. Langkah yang dilakukan Pemerintah patut diapresiasi, bantuan-bantuan khusunya untuk komoditi sembako seperti beras untuk tiap KK yang terdaftar sebagai masyarakat penerima bantuan sosial beras (BSB) di Kota Surabaya. Yang diharapkan lewat pemberian bantuan ini warga Kota Surabaya dapat terbantu dalam pemenuhan kebutuhan lewat pendistribusian beras tersebut.

3. Pemberdayaan masyarakat supaya mampu memanfaatkan pangan beragam, bergizi seimbang dan aman (B2SA) berbasis sumber daya lokal.

Dalam Perwali No. 56 Tahun 2016 BAB 3 Bagian 3 Bidang Pangan Pasal 7 ayat aa menyebutkan bahwa pelaksanaan promosi konsumsi pangan B2SA berbasis sumber daya lokal, dihitung dari konsumsi pangan per komoditas per kapita dalam setahun dan pelaksanaan pengawasan pangan segar yang beredar (Peraturan Walikota Surabaya Nomor 99 2016). Menurut Badan Ketahanan Pangan, tujuan utama Gerakan ini adalah meningkatkan kesadaran dan membudayakan pola konsumsi pangan B2SA guna hidup sehat, aktif, dan produktif kepada masyarakat (Badan Ketahanan Pangan Kementerian Pertanian n.d.). Gerakan ini juga ditujukan dalam penerapannya pula sesuai dengan langkah tujuan, sasaran, dan ruang lingkup, sebagai berikut, 


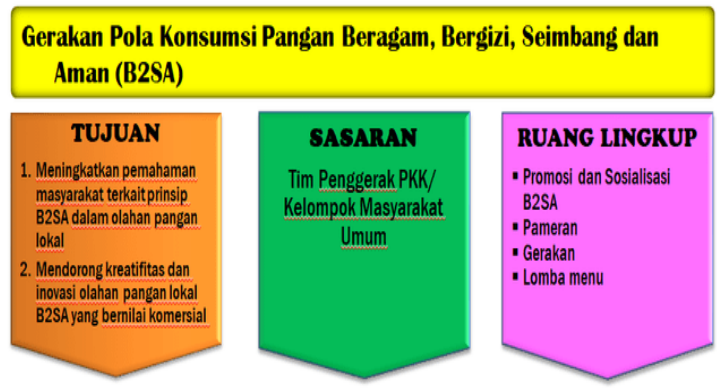

Gambar 8. Diagram tujuan, sasaran, dan ruang lingkup Gerakan pola konsumsi pangan beragam, bergizi, seimbang, dan aman (B2SA)

Sumber : Badan Ketahanan Pangan

Dalam hal ini meningkatkan kesejahteraan dalam peningkatan dan perkembangan yang dilakukan melalui berbagai kegiatan penunjang pengembangan ekonomi serta pemberdayaan masyarakat Kota Surabaya untuk dapat meningkatkan kemampuan masyarakat dalam menaikkan hasil produksinya(Krisnawati 2016). Dalam penerapan terkait pemberdayaan masyarakat lewat program Urban Farming untuk meningkatkan ketahanan pangan di masyarakat Pemerintah Kota Surabaya melakukan berbagai kegiatan pendukung seperti pemberian bantuan pendampingan dan pemberian bibit tanaman oleh Dinas Ketahanan Pangan dan Pertanian (Lawan COVID-19 2020).

Dalam program yang diberikan tersebut, kemudahan untuk mencapai pemberdayaan yang mampu memanfaatkan program Urban Farming dirasa perlu diberikan pelatihan maupun sosialisasi yang merupakan fungsi kelompok dalam individu (Tukiman, N, and Trisna 2019). Sesuai dengan pernyataan tersebut, langkah pemerintah dalam pemanfaatan program dengan pemberian pendampingan dan bantuan stimulan kepada masyarakat untuk memaksimalkan tanah pekarangannya maupun lahan-lahan tidak terpakai melalui Urban Farming, yang dimanfaatkan dengan tanaman pangan maupun hortikultura. Hal ini sejalan dengan anjuran bahwa dalam civil society sebuah kelompok dibentuk untuk mencapai tujuan yang sama, sehingga dapat dikatakan pelatihan maupun sosialisasi dalam pembinaan dirasa sangat tepat (Mahardhani, Sulton, and Sunarto 2020).

Bantuan yang diberikan berupa pemberian bibit baik secara kelompok maupun perseorangan yang nantinya diharapkan masyarakat mulai merubah perilaku nya untuk mencapai tingkatan ketahanan pangan yang tercukupi di masa Pandemi COVID-19 ini ada baiknya untuk menerapkan program Urban Farming selain guna pemenuhan kebutuhan baik difokuskan kepada masyarakat miskin ataupun yang terdampak langsung namun juga ditujukan untuk seluruh warga, apalagi selain efek positif nantinya yang didapat dari kebutuhan pangan yang tercukupi, masyarakat juga membantu pemerintah dalam hal membuka Ruang Terbuka Hijau.

Sebagai bukti nyata pemberdayaan masyarakat dapat ditemukan dalam pemanfaatan program Urban Farming yaitu di wilayah binaan KRPL Wonocolo menghasilkan produk serta pengolahan pangan berupa minuman berbahan dasar jeruk nipis dan serai yang bernama SERPIS (Dinas Ketahanan Pangan dan Pertanian Kota Surabaya 2020). Selain di wonocolo, pengolahan produk sebagai bentuk pemberdayaan masyarakat yang berhasil dilakukan ditujukan dari KRPL Sri Rejeki yang ada di wilayah kecamatan Sukomanunggal Surabaya yang memanfaatkan pengolahan tanaman TOGA menjadi produk minuman kesehatan (DKPP Kota Surabaya 2020c).

Tujuan pemberdayaan ini sendiri untuk membekali masyarakat agak memiliki edukasi serta kemauan untuk maju dalam melakukan kegiatan terkait pemanfaatan Urban Farming dengan menjunjung kualitas serta manfaat produk pangan yang beragam, bergizi seimbang dan aman (B2SA).

4. Promosi dan edukasi kepada masyarakat untuk memanfaatkan pangan B2SA berbasis sumber daya lokal.

Sejak adanya pandemi COVID-19 Pemerintah Kota Surabaya menggalakkan lagi tren pemanfaatan program ini yang bertujuan untuk pemenuhan dan peningkatan strategi ketahanan pangan yang dimulai dari individu maupun kelompok kecil pada rumah tangga keluarga.

Salah satu bentuk promosi yang gencar dilakukan oleh Dinas Ketahanan Pangan dan Pertanian terdapat pada setiap kegiatan yang di dokumentasikan lewat media sosial Instagram seperti edukasi yang dituangkan dalam kegiatan penanaman ketela (DKPP Kota Surabaya 2020), edukasi berupa poster poster yang di upload seperti bagaimana cara menanam tanaman melalui media hidroponik (DKPP Kota Surabaya 2020), serta promosi terkait bagaimana alur permohonan bibit dalam mendukung program pertanian perkotaan di Kota Surabaya (DKPP Kota Surabaya 2020).

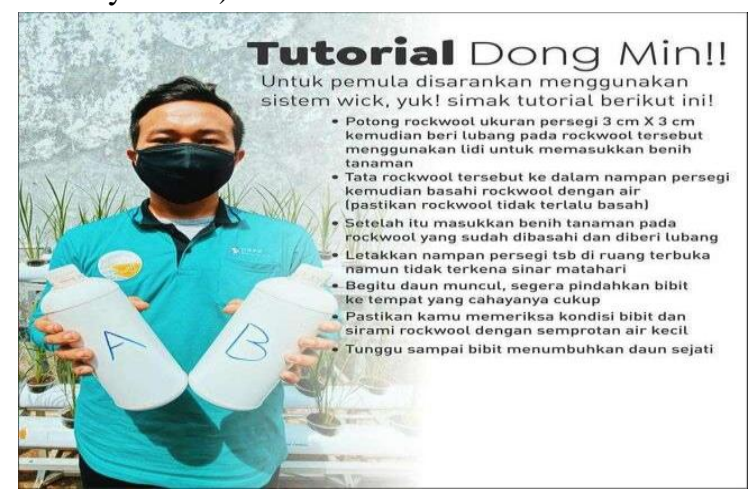


Gambar 11. Edukasi tahapan menanam dalam media Hidroponik

Sumber : Media Sosial Instagram Dinas Ketahanan Pangan dan Pertanian.

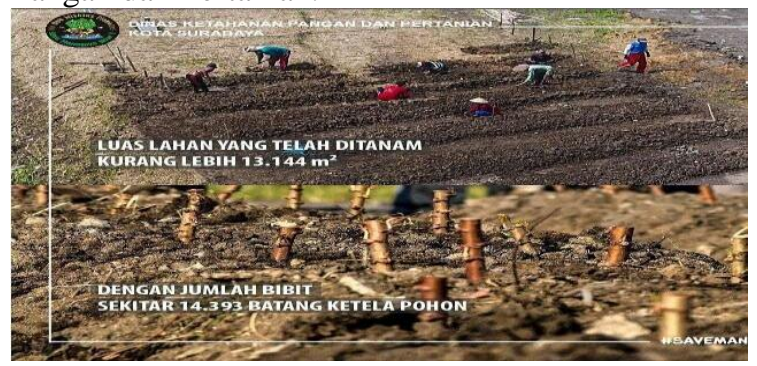

Gambar 12. Kegiatan edukasi menanam ketela pohon pada lahan kosong di Kota Surabaya

Sumber : Media Sosial Instagram Dinas Ketahanan Pangan dan Pertanian.

Dalam hal ini promosi dan edukasi yang paling penting adalah bagaimana cara masyarakat untuk memanfaatkan program tersebut tanpa kendala, yang kita ketahui bahwa wilayah lahan kosong di Kota Surabaya juga tidak banyak, sehingga yang dilakukan pemerintah Kota Surabaya oleh Dinas Ketahanan Pangan yakni melakukan sosialisasi terkait contoh menanam tanaman hidroponik yang tidak memerlukan lahan besar karena sangat mudah dilakukan dengan sedikit ruang saja(Qowiyyum et al. 2020). Selain itu langkah dalam promosi yang dilakukan pemerintah ditunjukkan lewat adanya bazar online yang diadakan oleh Bu Risma selaku Walikota Surabaya dengan rincian acara yang berisi kegiatan memasarkan produk pertanian mulai dari pertanian pangan maupun sayur mayur hingga hasil ikan segar yang di budidayakan para nelayan maupun warga binaan Dinas yang memasarkan produknya lewat adanya bazar online (Rachman 2020). Bazar tersebut dilakukan sebagai ajang promosi dalam pemasaran produk-produk hasil dari pemanfaatan program Urban Farming baik pangan seperti padi, jagung, gandum, juga terdapat pula tanaman sayur dan buahbuahan lewat hidroponik. Adanya fasilitas pemasaran di Fresh Market Citraland juga digunakan sebagai ajang promosi oleh Pemerintah apalagi dengan adanya inovasi pembayaran cashless yang ada juga mempermudah para pembeli yang masih takut untuk berinteraksi lebih intens dengan penjual di masa pandemi COVID-19 (Wijayanto 2020).

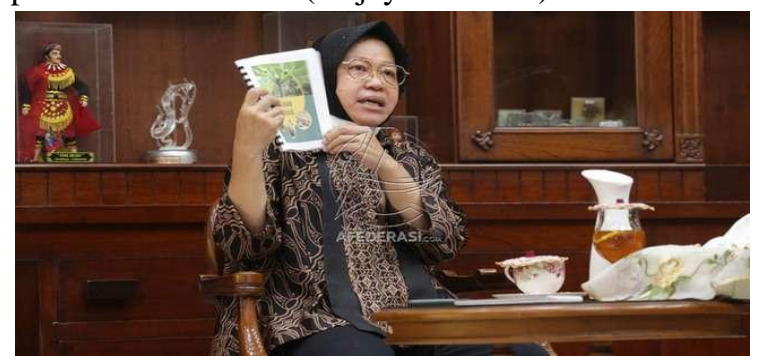

Gambar 13. Bazar Online yang dipimpin langsung oleh Bu Risma selaku Walikota Surabaya

Sumber : Dokumentasi DetikFinance 2020

5. Penanganan keamanan dan mutu pangan segar.

Dalam hal yang menyangkut kedalam keamanan suatu bahan pangan tentunya Pemerintah menyiapkan berbagai langkah pengawasan terhadap hal-hal yang bersinggungan dengan pelaksanaan distribusi bahan pokok apalagi dimasa pandemi COVID-19. Merujuk dalam pengawasan keamanan pangan yang dibagi sesuai kewenangan pada Peraturan Pemerintah No 28 tahun 2004 berisikan kewenangan pengawasan keamanan sesuai anjuran BPOM yang dilakukan oleh BKP (BKP 2020).

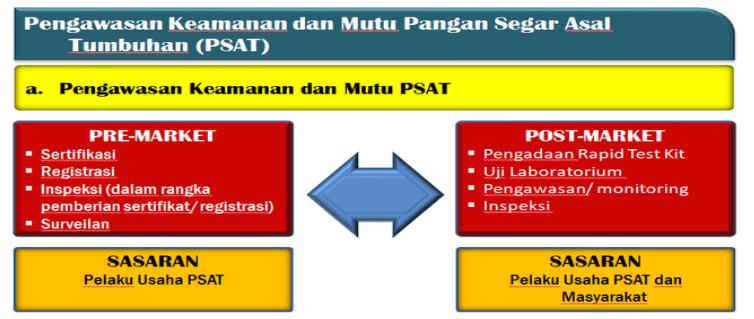

Gambar 12. Alur Pengawasan Keamanan dan Mutu Pangan Segar Asal Tumbuhan (PSAT)

Sumber : Badan Ketahanan Pangan 2020

Sehingga dalam alur diatas adanya pengawasan yang sangat ketat di masa pandemi COVID-19 dalam kegiatan jual beli produk pangan seperti adanya rapid test kit serta uji laboratorium segala komoditi pangan yang akan dipasarkan sehingga akan meminimalisir angka pertumbuhan kasus dalam COVID-19. Contoh lain adanya penerapan khusus seperti pada saat Idul Adha, DKPP juga memberikan himbauan dalam tata cara maupun tahapan dalam penyembelihan hewan qurban maupun bagaimana proses penjualan dan pendistribusian sesuai dengan protokol kesehatan tentang Pedoman Pelaksanaan Kegiatan Idul Qurban 1441 H Pada Kondisi saat meluasnya virus corona yang tertuang dalam Surat Edaran Walikota Nomor 003.2/6362/436.8.4/2020 (DKPP 2020). Sehingga baik pangan hewani maupun sumber pangan dari tumbuhan dapat terjamin mutunya sesuai dengan anjuran pengawasan yang dituliskan oleh Badan Ketahanan Pangan Kementerian Pertanian.

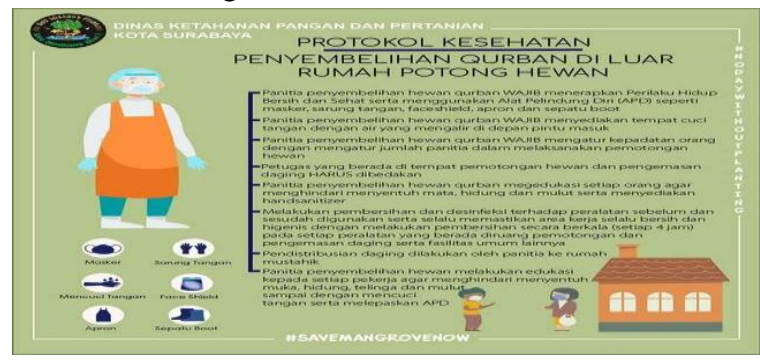




\section{Gambar 14. Protokol Kesehatan dalam penyembelihaan hewan qurban}

Sumber : Media Sosial Instagram Dinas Ketahanan Pangan dan Pertanian.

\section{Ucapan Terima Kasih}

Peneliti ingin memberikan untaian terima kasih kepada :

1. Seluruh Dosen S1 Ilmu Administrasi Negara Fakultas Ilmu Sosial dan Hukum Universitas Negeri Surabaya.

2. Ibu Fitrotun Niswah, S.AP.,M.AP. selaku dosen pembimbing artikel skripsi.

3. Ibu Dra. Meirinawati, M.AP. selaku dosen penguji artikel skripsi.

4. Bapak Trenda Aktiva Oktariyanda, S.AP.,M.AP. selaku dosen penguji artikel skripsi.

5. Seluruh keluarga, Bapak, Ibu, dan ketiga Adik saya yang telah memberikan dukungan baik moril maupun materiil dalam proses pengerjaan artikel skripsi.

6. Teman-teman JAPS1ANA terutama widiwidi yang berjuang bersama dalam pengerjaan artikel ini serta sahabat saya yang sangat berharga lili dan amel yang memberi dukungan, bantuan, dan selalu bersama dalam suka maupun duka saat artikel ini dibuat.

7. 23 anggota NCT, 9 anggota EXO, dan seluruh idol KPOP lain yang telah menjadi penyemangat dan selalu menemani peneliti disaat mengalami hambatan mental dalam proses pengerjaan artikel ini.

8. Dan terimakasih untuk quotes yang tertuang dalam lagu Kim Jonghyun - End of The Day untuk selalu yakin bahwa apa yang sudah saya kerjakan patut diapresiasi dengan kalimat "Kamu telah bekerja keras hari ini"

\section{PENUTUP}

\section{Simpulan}

Dalam pemenuhan kebutuhan untuk mencapai ketahanan pangan diperlukannya strategi-strategi yang nantinya diharapkan sebagai obat untuk mengatasi permasalahan-permasalahan yang diakibatkan oleh COVID-19 seperti kelangkaan yang ada di beberapa komoditi seperti bawang putih yang sempat mengalami peningkatan harga dikarenakan kelangkaan yang terjadi. Pengambilan data lewat metode studi kepustakaan juga dianjurkan dikarenakan masih adanya sebaran COVID-19 di Kota Surabaya sehingga diperlukannya pembatasan interaksi satu sama lain yang masih diterapkan di tiap Dinas sehingga langkah penggunaan metode penelitian yang relevan dan bisa menyesuaikan keadaan saat ini.

Dari ke 5 strategi menurut Hanafie, 2010 menunjukkan bahwa di tiap indikator dalam mencapai strategi akan pangan yang dianjurkan oleh Badan Ketahanan Pangan Kementerian Pertanian telah dilakukan dengan penyesuaian di masa pandemi COVID-19 sehingga dari ke 5 strategi yang diuraikan secara rinci dalam indikator prioritas pembangunan ekonomi berbasis pertanian yang dimanfaatkan di perkotaan; pemenuhan pangan pasca pandemi COVID-19 yang direalisasikan dalam distribusi bantuan pangan; pemberdayaan masyarakat terkait program Urban Farming dengan adanya pelatihan serta pembinaan; promosi dan edukasi terkait program tersebut; dan penanganan keamanan terhadap jaminan mutu pangan yang segar; sehingga peran dan langkah yang dilakukan Pemerintah Kota Surabaya dinilai sangat efektif. Hal ini ditinjau lewat meningkatnya tren positif dalam pemanfaatan program Urban Farming oleh masyarakat Kota Surabaya.

Sehingga bisa disimpulkan bahwa pada setiap indikator yang telah dianalisis menemukan fakta bahwa teori tersebut relevan untuk mengkaji hal yang diperlukan dalam membuat strategi ketahanan pangan melalui program pertanian perkotaan yang dinakaman Urban Farming yang dikelola Dinas yang spesifiknya mengatur ketahanan pangan serta jalannya pertanian di Kota Surabaya dalam hal pemenuhan kebutuhan individu masing-masing lewat perbaikan yang dilakukan melalui dijalankannya tren menanam dalam suatu arahan yang dinamakan pertanian perkotaan Urban Farming.

\section{Saran}

Menurut penelitian yang dilakukan ini, saran peneliti dalam strategi yang diterapkan untuk meningkatkan ketahanan pangan Kota Surabaya yang nantinya dapat digunakan serta dimanfaatkan pemerintah dalam hal ini Dinas Ketahanan Pangan dan Pertanian Kota Surabaya agar lebih fokus memperbaiki serta mengatasi permasalahan akan pemenuhan kebutuhan pangan di masa pandemi COVID-19 yang diuraikan kedalam beberapa poin diantaranya :

1. Dalam sosialisasi dan edukasi kepada masyarakat lewat media yang ada, masih belum adanya informasi lebih lanjut lewat media sosial seperti instagram ataupun twitter untuk ajakan Urban Farming. Namun masih belum banyak masyarakat yang melek teknologi sehingga perlu pula media promosi serta edukasi lainnya. 
2. Dalam pendataan masyarakat miskin penerima bantuan pangan ada baiknya dilakukan survei kembali karena pandemi COVID-19 tidak hanya mempengaruhi masyarakat kalangan bawah saja.

3. Dikarenakan COVID-19 kegiatan seperti pemasaran produk pertanian lebih ditinjau kembali pelaksanaannya serta tetap menerapkan protokol kesehatan yang dianjurkan.

4. Perlunya wadah pemasaran yang didirikan dikarenakan pada Citraland Fresh Market selain akses wilayah yang cukup jauh dari tengah kota serta lingkungan masyarakat yang termasuk kedalam kalangan atas sehingga sasaran terkait pemasaran produk untuk warga menengah kebawah dirasa tidak tepat.

5. Pemberdayaan terkait pembinaan yang lebih diawasi dikarenakan akibat adanya social distancing tentunya interaksi harus dibatasi.

6. Dapat menyajikan inovasi baru terkait produk pengolahan dalam pemanfaatan program Urban Farming.

7. Adanya kerjasama antara masyarakat dan pemerintah yang lebih ditingkatkan guna meningkatkan ketahanan pangan khususnya di Kota Surabaya.

\section{DAFTAR PUSTAKA}

Andoko, Effendi, and Aurellia Candida Doretha. 2019. "Analysis of Indonesian Government Strategies to Food Security: Harnessing the Potential of Natural and Human Resources." FF Agricultural Policy Platform (FFTC-AP) 1-1. Retrieved January 10, 2021 (https://ap.fftc.org.tw/article/1588).

ANP. 2020. "44 Ribu Keluarga Di Surabaya Nikmati Beras Medium Bantuan Kemensos | Mnctrijaya.Com." Mnctrijaya.Com 1-1. Retrieved January 10,2021 (https://mnctrijaya.com/news/detail/36356/44-ribukeluarga-di-surabaya-nikmati-beras-mediumbantuan-kemensos).

Badan Ketahanan Pangan Kementerian Pertanian. n.d. "BKP - Gerakan Konsumsi Pangan Beragam Bergizi Seimbang Dan Aman (B2SA)." BKP. Retrieved January $10, \quad 2021$ (http://bkp.pertanian.go.id/gerakan-konsumsipangan-beragam-bergizi-seimbang-dan-amanb2sa).

Badan Pusat Statistik. 2020. "Perkembangan Nilai Tukar Petani Jawa Timur Bulan Mei 2020.” (April):1-7.

Bakalis, Serafim, and Vasilis P. Valdramidis. 2020. "Perspectives from CO+RE: How COVID-19
Changed Our Food Systems and Food Security Paradigms." Current Research in Food Science 3(June):166-72. doi: 10.1016/j.crfs.2020.05.003.

BKP. 2020a. "BKP - Kementan Siapkan Strategi Ketahanan Pangan Di Tengah Pandemi Covid-19." Badan Ketahanan Pangan Kementerian Pertanian 1-1. Retrieved January 10, 2021 (http://bkp.pertanian.go.id/blog/post/kementansiapkan-strategi-ketahanan-pangan-di-tengahpandemi-covid-19).

BKP. 2020b. "BKP - Pengawasan Keamanan Dan Mutu Pangan Segar." BKP Kementerian Pertanian. Retrieved January 11, 2021 (http://bkp.pertanian.go.id/pengawasan-keamanandan-mutu-pangan-segar).

BPS. 2020. "Profil Kemiskinan Di Indonesia Maret 2020." Berita Resmi Statistik (56):1-12.

Carzedda, Matteo, and Federico Nassivera. 2021. "Urban Food Security and Strategic Planning: Involving Millennials in Urban Agriculture." Pp. 91-100 in Smart Innovation, Systems and Technologies. Vol. 178 SIST. Springer Science and Business Media Deutschland GmbH.

Chen, Kevin Z., and Rui Mao. 2020. "Fire Lines as Fault Lines: Increased Trade Barriers during the COVID19 Pandemic Further Shatter the Global Food System." Food Security 12(4):735-38. doi: 10.1007/s12571-020-01075-2.

CNN Indonesia, Bulog. 2020. "Bulog Salurkan Bansos Beras Pada 10 Juta Keluarga Terdampak." Cnnindonesia.Com 1-1. Retrieved January 10, 2021 (https://www.cnnindonesia.com/ekonomi/2020110 4150348-97-565869/bulog-salurkan-bansos-beraspada-10-juta-keluarga-terdampak).

Dinas Ketahanan Pangan dan Pertanian Kota Surabaya. 2020. "KRPL (Kawasan Rumah Pangan Lestari) SERPIS - YouTube.” DKPP Youtube Channel 1-1. Retrieved January 10, 2021 (https://www.youtube.com/watch?v=bO1cwz1fwlE ).

DKPP. 2020. "DKPP Kota Surabaya on Instagram." DKPP Kota Surabaya 1-1. Retrieved January 11, 2021

(https://www.instagram.com/p/CC0BIA8FZqu/?igs hid=16rmgoqcmvaae).

DKPP Kota Surabaya. 2020a. "DKPP Kota Surabaya on Instagram." Dinas Ketahanan Pangan Dan Pertanian Kota Surabaya 1-1. Retrieved January 10, 2021 (https://www.instagram.com/p/CBMj7PPIX4s/).

DKPP Kota Surabaya. 2020b. "DKPP Kota Surabaya on Instagram." Dinas Ketahanan Pangan Dan Pertanian Kota Surabaya 1-1. Retrieved January 11, 2021 (https://www.instagram.com/p/CCf2ZrVlWxo/?igs 
hid=j2swersliq4z).

DKPP Kota Surabaya. 2020c. "KRPL SRI REJEKI YouTube." Dinas Ketahanan Pangan Dan Pertanian Kota Surabaya 1-1. Retrieved January 10 , 2021

(https://www.youtube.com/watch?v=AKMECJcnU _w\&t=21s).

Elmer E. Rasmuson Library. 2020. "Library Research Process." UAF 1-1. Retrieved January 10, 2021 (https://library.uaf.edu/ls101-research-process).

Hagey, Allison, Solana Rice, and Rebecca Flournoy. 2012. "Growing Urban Agriculture : Equitable Strategies and Policies for Improving Access to Healthy Food and Revitalizing Communities." 52.

Hakim, Abdul, and Erafzron Saptiyulda AS. 2020. "Urban Farming Diminati Warga Surabaya Saat Pandemi COVID-19 - ANTARA News." Antaranews.Com 1-1. Retrieved January 10, 2021 (https://www.antaranews.com/berita/1609910/urba n-farming-diminati-warga-surabaya-saat-pandemicovid-19).

Hanafie, Rita. 2010. Pengantar Ekonomi Pertanian. I. Yogyakarta: Penerbit Andi.

Humas Bangga Surabaya. 2020. "Pengembangan Urban Farming Dan Diversifikasi Pangan Untuk Penguatan Ketahanan Pangan Kota Surabaya - Bangga Surabaya." Humas Bangga Surabaya 1-1. Retrieved January $10, \quad 2021$ (https://humas.surabaya.go.id/2020/08/24/pengemb angan-urban-farming-dan-diversifikasi-panganuntuk-penguatan-ketahanan-pangan-kotasurabaya/).

Khoirunnas, Fajar. 2019. "Manajemen Strategi Taman Teknologi Pertanian (TTP) Di Desa Banyubang Kecamatan Solokuro Kabupaten Lamongan." Publika Vol 5(No. 3):1-8.

Komarudin. 2020. "Mengintip Peluang Urban Farming Saat Pandemi - Lifestyle Liputan6.Com." Liputan6.Com 1-1. Retrieved January 10, 2021 (https://www.liputan6.com/lifestyle/read/4272049/ mengintip-peluang-urban-farming-saat-pandemi).

Komite Penanganan COVID-19 dan Pemulihan Ekonomi Nasional. 2020. "Peta Sebaran COVID-19 | Satgas Penanganan COVID-19.” 1-1. Retrieved January 10, $2021 \quad$ (https://covid19.go.id/peta-sebarancovid19).

Krisnawati, Atika. 2016. "Model Pemberdayaan Masyarakat Melalui Konsep Pertanian Perkotaan (Urban Farming) (Studi Pada Kelompok Tani Elok Mekar Sari Kelurahan Semolowaru Kota Surabaya)." Publika 4(4):1-11.

Kurnia, Dadang, and Dwi Murdaningsih. 2020. "Pemkot Surabaya Terus Kembangkan Urban Farming | Republika Online.” Republika.Co.Id 1-1. Retrieved January

10 ,

2021 (https://republika.co.id/berita/qfk8e9368/pemkotsurabaya-terus-kembangkan-urban-farming).

Kurniawan, Dian. 2020. “231 Perusahaan Se-Jatim PHK 6.900 Karyawan Selama Pandemi COVID-19 Surabaya Liputan6.Com." Liputan6.Com 1-1. Retrieved January 10, 2021 (https://surabaya.liputan6.com/read/4272549/231perusahaan-se-jatim-phk-6900-karyawan-selamapandemi-covid-19).

Lawan COVID-19. 2020. "Surabaya Tanggap COVID19." Surabaya Lawan COVID-19 1-1. Retrieved January 10, $2021 \quad$ (https://lawancovid19.surabaya.go.id/beritapemkot/baca/pengembangan-urban-farming-dandiversifikasi-pangan-untuk-penguatan-ketahananpangan-kota-surabaya).

Liputan6.com. 2020. “Genjot Ekonomi Warga, Pemkot Surabaya Kembangkan Urban Farming - Surabaya Liputan6.Com." Surabaya Liputan6 1-1. Retrieved January $10, \quad 2021$ (https://surabaya.liputan6.com/read/4337698/genjot -ekonomi-warga-pemkot-surabaya-kembangkanurban-farming).

Made, I. Dewa, and Dwi Uli. 2020. "Indonesia's Food Security Under Threat | The ASEAN Post." The Asean Post 1. Retrieved January 10, 2021 (https://theaseanpost.com/article/indonesias-foodsecurity-under-threat).

Mahardhani, Ardhana Januar, Sulton Sulton, and Sunarto Sunarto. 2020. "Peran Civil Society Organization (Cso) Dalam Perumusan Kebijakan Publik (Kajian Di Kabupaten Ponorogo)." JPSI (Journal of Public Sector Innovations) 4(2):59-62. doi: 10.26740/jpsi.v4n2.p59-62.

Mahardika, Wayan A., and Bambang Priyo Jatmiko. 2020. "Mentan Pastikan Pasokan Bawang Putih Aman, Meski Impor Dari China Dihentikan Halaman All Kompas.Com." Kompas.Com 1-1. Retrieved January $\quad 10, \quad 2021$ (https://money.kompas.com/read/2020/02/03/22420 0126/mentan-pastikan-pasokan-bawang-putihaman-meski-impor-dari-chinadihentikan?page=all).

Nazir, M. 2019. "Metode Penelitian (Jakarta: Ghalia Indonesia)." Digilib Uinsa 12(27-41):41-47.

Panuju, Dyah R., Kei Mizuno, and Bambang $\mathrm{H}$. Trisasongko. 2013. "The Dynamics of Rice Production in Indonesia 1961-2009." Journal of the Saudi Society of Agricultural Sciences 12(1):27-37. doi: 10.1016/j.jssas.2012.05.002.

Peraturan Walikota Surabaya Nomor 99. 2016. "Walikota Surabaya Provinsi Jawa Timur.” 1994:1-7.

Qowiyyum, Erfandy Budi, Olivia Agustin Nailatul Wardah, and Dkk. 2020. "Implementasi Program Urban Farming Dinas Ketahanan Pangan Dan 
Pertanian Kota Surabaya." Researchgate 1(October):54.

Rachman, Fadhly Fauzi. 2020. “Genjot Ekonomi Saat Pandemi, Risma Buka Bazar Online." DetikFinance 1-1. Retrieved January 11, 2021 (https://finance.detik.com/berita-ekonomi-bisnis/d5162637/genjot-ekonomi-saat-pandemi-rismabukabazar-online).

Rahman, Dzulfiqar Fathur. 2020. "Pandemic Disrupts Food Distribution across Country, Minister Says Business - The Jakarta Post." The Jakarta Post 1-1. Retrieved January 10, 2021 (https://www.thejakartapost.com/news/2020/07/14/ pandemic-disrupts-food-distribution-acrosscountry-minister-says.html).

Rep, Jurnal, and Riset Ekonomi Pembangunan. 2006. "The Strategy To Build Food Security and Poverty." Jurnal REP (Riset Ekonomi Pembangunan) 3(1):263-76.

Santoso, Eko Budi, Rini Ratna, Widya;. Gerakan, Pertanian Perkotaan, Kota Surabaya, and Rini Ratna Widya. 2014. "Gerakan Pertanian Perkotaan Dalam Mendukung Kemandirian Masyarakat Di Kota Surabaya." Seminar Nasional Cities 16(November): 11 .

Sihgiyanti;, Vika Jessy. 2016. "Evaluasi Implementasi Program Urban Farming Oleh Dinas Pertanian Di Kota Surabaya." Kebijakan Dan Manajemen Publik 4(2):264-72.

Siregar, Efrem. 2019. "Impor Buah Dan Sayur Rp2,4 Triliun, Sayuran Ini Juaranya." CNBC Indonesia $1-$ 1. Retrieved January 10, 2021 (https://www.cnbcindonesia.com/news/201909171 54835-4-100093/impor-buah-dan-sayur-rp24triliun-sayuran-ini-juaranya).

Timmer, C. Peter. 2019. "Food Security in Indonesia: Current Challenges and the Long-Run Outlook." Researchgate 48(May):23.

doi: 10.2139/ssrn.1112807.

Transiskom.com. 2016. "Pengertian Studi Kepustakaan." Transiskom.Com 1-1. Retrieved January 10, 2021 (https://www.transiskom.com/2016/03/pengertianstudi-kepustakaan.html).

Tukiman, Ertien Rining N, and Andre Yusuf Trisna. 2019. "Pemberdayaan Kelompok Wanita Tani Dalam Usaha Pembuatan Abon Dengan Bahan Dasar Dari Jantung Pisang Di Desa Dompyong Kecamatan Bendungan Kabupaten Trenggalek.” JPSI (Journal of Public Sector Innovations) 4(1):38-45.

Undang-undang, No 17. 2015. "Peraturan Pemerintah Tentang Ketahanan Pangan." Peraturan Pemerintah Tentang Ketahanan Pangan.

Wijayanto. 2020. "CitraLand Terapkan Protokol Kesehatan Ketat Di Fresh Market Dan GWalk." Radarsurabaya.Jawapos.Com 1-1. Retrieved
January $\quad 10, \quad 2021$ (https://radarsurabaya.jawapos.com/read/2020/09/1 6/214088/citraland-terapkan-protokol-kesehatanketat-di-fresh-market-dan-gwalk).

Wiyanti, Annisya Noer. 2013. "Implementasi Program Urban Farming Pada Kelompok Sumber Trisno Alami Di Kecamatan Bulak Kota Surabaya." Publika I, No. 2:1-15.

Yuana, Lely, and Irfan Anshori. 2020. "Sektor Ekonomi Kota Mandiri CitraLand Surabaya Kembali Bergairah | TIMES Indonesia." Timesindonesia.Co.Id 1-1. Retrieved January 10, 2021

(https://www.timesindonesia.co.id/read/news/2952

23/sektor-ekonomi-kota-mandiricitraland-surabayakembali-bergairah).

Zahro, Fatimatus, and Saiful Sholichfudin. 2020. "Produk Hidroponik Surabaya Mulai Dijual Di Fresh Market Pasar Modern Citraland - YouTube." Harian Surya 1-1. Retrieved January 10, 2021 (https://www.youtube.com/watch?v=q4MYsELxQz c). 
Publika. Volume 9 Nomor 1 Tahun 2021, 145-160 